\title{
LAGOA DE SANTO ANDRÉ (SW PORTUGAL): PHYTOPIGMENTS AS SEDIMENTARY TRACERS
}

\author{
L. Cancela Da Fonseca*; A. M. Costa**;J. M. Bernardo** y R. Fonseca*** \\ * Dept.Zool. Antropol.,Fac. de Cienc. Lisb., Lab. Marit.Guia, P-2750Cascais \\ ** Dept. Ecologia, Univ. Evora, P-7000 Evora \\ ${ }^{* * *}$ Laboratório Marítimoda Guia, P-2750 Cascais
}

Key words: Coastal Lagoons. Phytopigments. Sediments.

\begin{abstract}
During the last years, the study of chlorophyll a and its derivatives is increasingly used in the understandingof productivity phenomena of aquatic sediments. St. André is a coastal brackish lagoon, with large amountsof organic matter in the surface sediments. This paper deals with phytopigments, organic matter (losson ignition), water content and granulometry of the sediments.Twodistinctzonesof productivityarecloselyrelated with themain sediment types: sands and muds. Phaeopigments correlate well with organic matter emphasizing its vegetal origin. Muds presenta larger pigment concentrationbut it seems thatalso in the sandy zone production prevailsover sedimentary processes.
\end{abstract}

\section{INTRODUCTION}

In recent years, the study of chlorophyll a and its derivatives have been increasingly used in the understanding of microphytobenthos productivity (Plante Cuny, 1977, 1979; Colijn \& Jonge, 1984). Many authors have reported sedimentary processes of chlorophyll $a$ and its decaying products (Sanger\& Gorham, 1972; Shuman \& Lorenzen, 1975; Brown et al., 1977; Birch et al 1980).

Benthic food chain of lagoons starting with microphytobenthos have a significant function on systems dynamics (Plante - Cuny, 1977).

Bottom pigments from rnicrophytobenthos, sunken phytoplankton, macrophytes and organic detritus deposition, have shown to be useful tracers of important phenomenain aquatic ecosystems (Fogg \& Belcher, 1961; Daley et al 1977; Reynolds et al 1982; Duxin, 1984).

Recently, microbenthic photosynthesis was related to eutrophication processes and biogeochemical dynamics at the sediment level (Sundback, 1986; Graneli \& Sundback, 1986).

Usually, the benthic phytopigments are studied from a paleolimnologic point of view as some of them persist through timeas biochemical 
fossils (Brownet al, 1977). They can often describe past environments(Lubienko\& Rauser-Cernooussova, 1930; Fox \& Anderson, 1941; Vallentyne 1954,1955; Vallentyne \& Crastow, 1957; Carpenter, 1986). From this point of view the interpretation of the past depends on the knowledge of present situations (Selley, 1976).

Detritus accumulating and non accumulating zones can be detected by sedimentary pigments. The origin of bottom organic matter is also detectable.

Santo André is a brackish water coastallagoon located on the SW coast of Portugal, separated from the sea by a sand barrier. The main phenomena in its annual cycle are precipitation (November to March)and the artificial connection to the sea (usually in early Spring, after the more intense run-off period, when the water level reaches its maximum).

In 1981 and 1982, the lagoon was permanently isolated. In 1983 the connection with the sea was formed very late in the year (July). No effective washing process took place and extreme eutrophication extended throughout the lagoon. After 1984, the inlet was opened every year at the right period (March). The 1984 opening period was very short. This factmay be related with unfavorable sea conditions and insufficient water in the lagoon. In 1985, witha large water volumeand no storm tides, the lagoon was connected to the sea for one and a half months.

Since 1984 a research project has been carried outconceming water, sediments, benthicand fish communities.

This study concerns grain-size distribution of surface sediments and its relations with water content, phytopigments and lossonignition as an organic matter approach.

\section{METHODS}

Samplesfrom 17 sampling points (Fig. 1)were taken each month from February 1984 to May 1985. During this period the connection with the sea was formed twice-March 1984, March-April 1985. For this study 9 months data was conside- red- February, March, April, July, September, October 1984 and February, March, May 1985.

A modified Van Veen grab $\left(0.05 \mathrm{~m}^{2}\right.$ - Sousa Reis model, L.M.G. 1983) was used. Two subsampleswere separated:) a $10 \mathrm{~cm}$ section for the grain-size study; 2) and an upper layer $(1 \mathrm{~cm})$ for watercontent, organic matter and phytopigments analysis (aliquotes frozen at $-20^{\circ} \mathrm{C}$ ).

Methods used were:

1) - Separation of mud $(>62 \mu)$, sand $(62 \mu-2000 \mu)$ and gravel $(>2000 \mu)$ by wet sieving (Buller \& McManus, 1979).

- Determination of sand grain-size distribution by dry sieving in the size grade -20 to $4 ø$ Wentworth scale, afterdestruction of organic matter $\left(\mathrm{H}_{2} \mathrm{O}_{2}, 130\right.$ vol. $)$.

2) - Estimate of sediment organic matter content (OM) by loss on ignition $\left(450^{\circ} \mathrm{C}\right.$ and $650^{\circ} \mathrm{C}$ during a $24 \mathrm{hr}$ period).

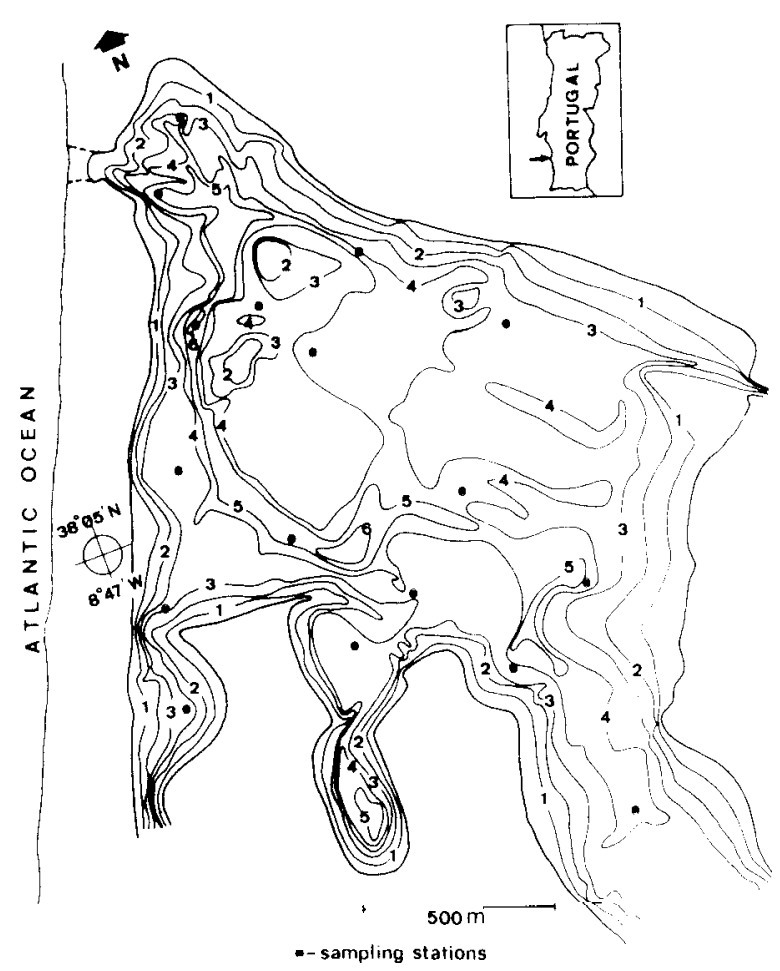

Figure 1.-St André Lagoon: February 1985 bathymetricsurvey. 


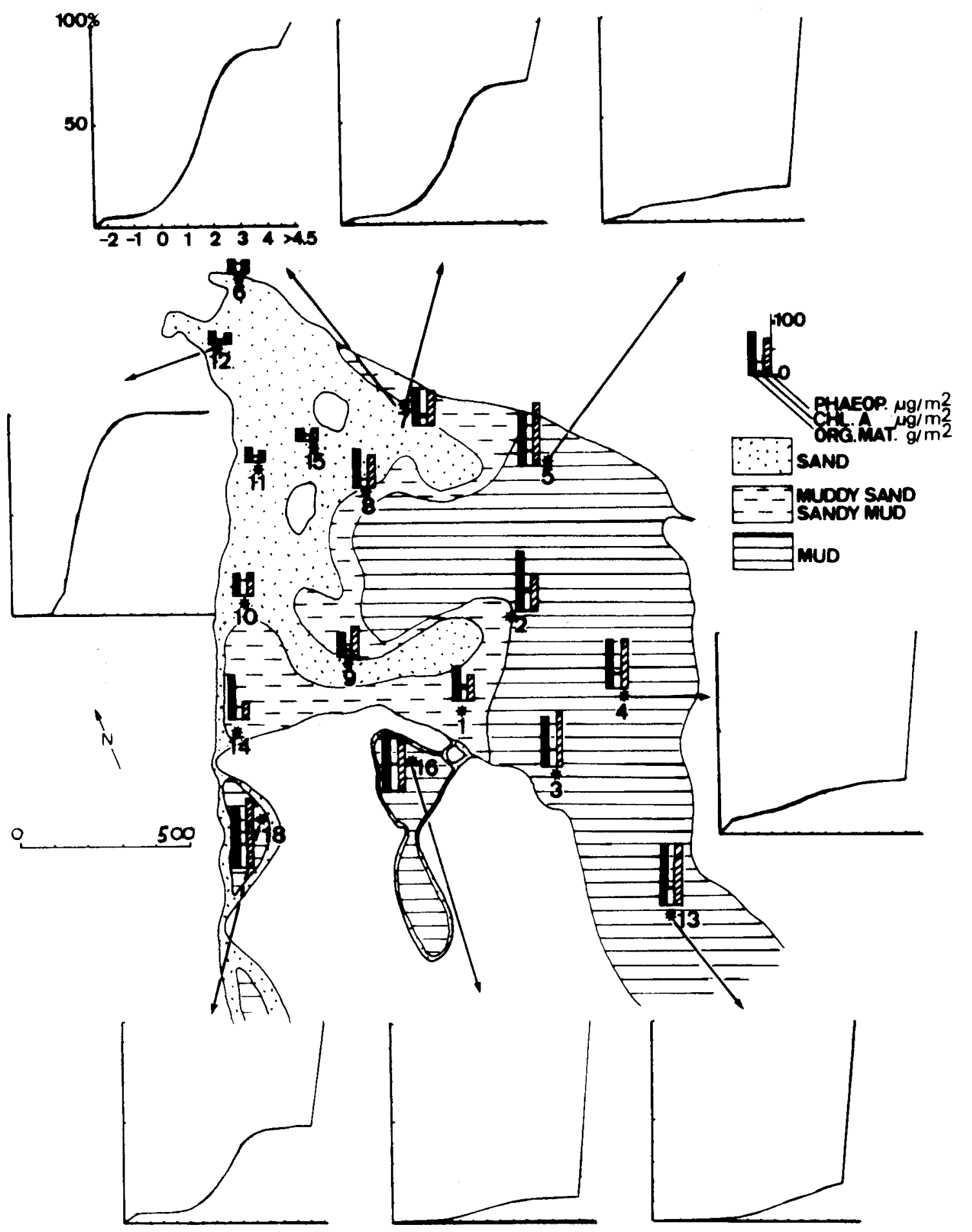

Figure 2.-St AndréLagoon:lithofacies, distribution of chlorophylla,phaeopigmentsandorganicmatterand representativeaverage cumulativefrequencycurves. 
- Sediment water content estimation $\left(\% \mathrm{H}^{2} \mathrm{O}\right)$ by $24 \mathrm{hr}$ drying at $65^{\circ} \mathrm{C}$.

- Evaluation of phytopigments concentration by spectrophotometry after $24 \mathrm{hr}$, cool extraction in $90 \%$ acetone.

Chlorophyll a (chla) and phaeopigments (phaeop)concentrations ( $\mathrm{g} / \mathrm{gdry}$ sediment)were calculated by modified Lorenzen equations (Plante-Cuny, 1974).

Abs410 (Abs410nm-Abs750nm x acet. vol./ weight dry sediment)and Abs430nm/Abs410nm (Moss, 1967) were calculated.

To obtain phytopigment values per unit area $\left(\mathrm{mg} / \mathrm{m}^{2}\right)$ from phytopigment values per weight $(\mu \mathrm{g} / \mathrm{g})$, a sediment specific weight was developed. Linear regression and correlation analysis was established between water percentage of several types of sediment and its respective sediment specific weight.

Cluster analysis (Bravais-Pearsoncoefficient and the single linkage clustenng method) was used to group parameters and stations.

In order to summanze the information Principal Components Analysis (PCA) was utilized on the average values of parameters for each sampling point. Data analysis was performed at Laboratório Mantimo da Guia with programs by Andrade (1986). Echo-sounding was used for the bathymetry. Transects were taken in February 1985 when water reached maximum level for the study period.

\section{RESULTS}

Annual average depth is $1.78 \mathrm{~m}$. Maximum depth occurred in February 1985-4.02maverage depth-when the bathymetric survey was carried out (Fig. 1). A channel, approximately $2 \mathrm{~m}$ deeper than the rest of the lagoon, is the ancient river bed of an estuary. This channel is intensively washed when the lagoon is subject to tidal action.

From the results of grain-size analysis, the distribution of lithofacies was mapped (Fig. 2). Organic matter content, chlorophylla and phaeopigments and cumulative curves of sediment are also presented in Fig. 2.
Average grain-size decreases from areas influenced by the sea, near the sand bar, to the interior, where deposition of finer particles predominantly takes place (Fonseca, 1985).

Along the annual cycle, the grain size modifications of the mud stations correspond, almost exclusively, to the coarser fraction (mainly bioclasts).

Energy and transport changes result in grainsize variation increase of fines or coarse material. These processes are related to the entry of silts and clays, macrophyte decomposition and communication with the sea.

Cluster analysis discriminates two main groups of sampling stations - sands and muds. The composition of each group is considerably constant when comparing each month analysis.

The same multivanate treatment applied to parameter monthly data showed a remarkable persistence of group composition. Dueto this fact we considered the parameters average values for the cluster analysis and the PCA treatment.

Cluster analysis on the averages values of parameters (Fig. 3) shows an inverse correlation $(p<0.05)$ between sand percentage, $430 / 410$ and all the other parameters. Chlorophyll a, phaeopigments, Abs410, OM 450, OM 650, and water percentage are positively correlated with mud percentage $(p<0.001)$ and with Margalef's index $(\mathrm{p}<0.05)$.

In Axis 1 of PCA (Fig. 4) sand percentage opposes to mud percentage and all the other associated parameters except $430 / 410$. Axis 2 mainly reflects the opposition between $430 / 410$ and phaeopigments.

In Axis 1 severa1distinct groups of stations are sequentially placed, from sands to muds, with two intermediate situations:

- sands (stations 6, 11, 12 and 15)

- sand stations changing in time and becoming more or less muddy (stations 7,9 and 10).

- muds changing to sandy muds in some penods (stations 1,8 and 14).

- muds (stations 2, 3, 4, 5, 13) emphasizing the specific character of 16 and 18 , located in the small lateral bays and so suffenng much less theeffectsof the spnng washingprocess when ocean waters enter the lagoon. 


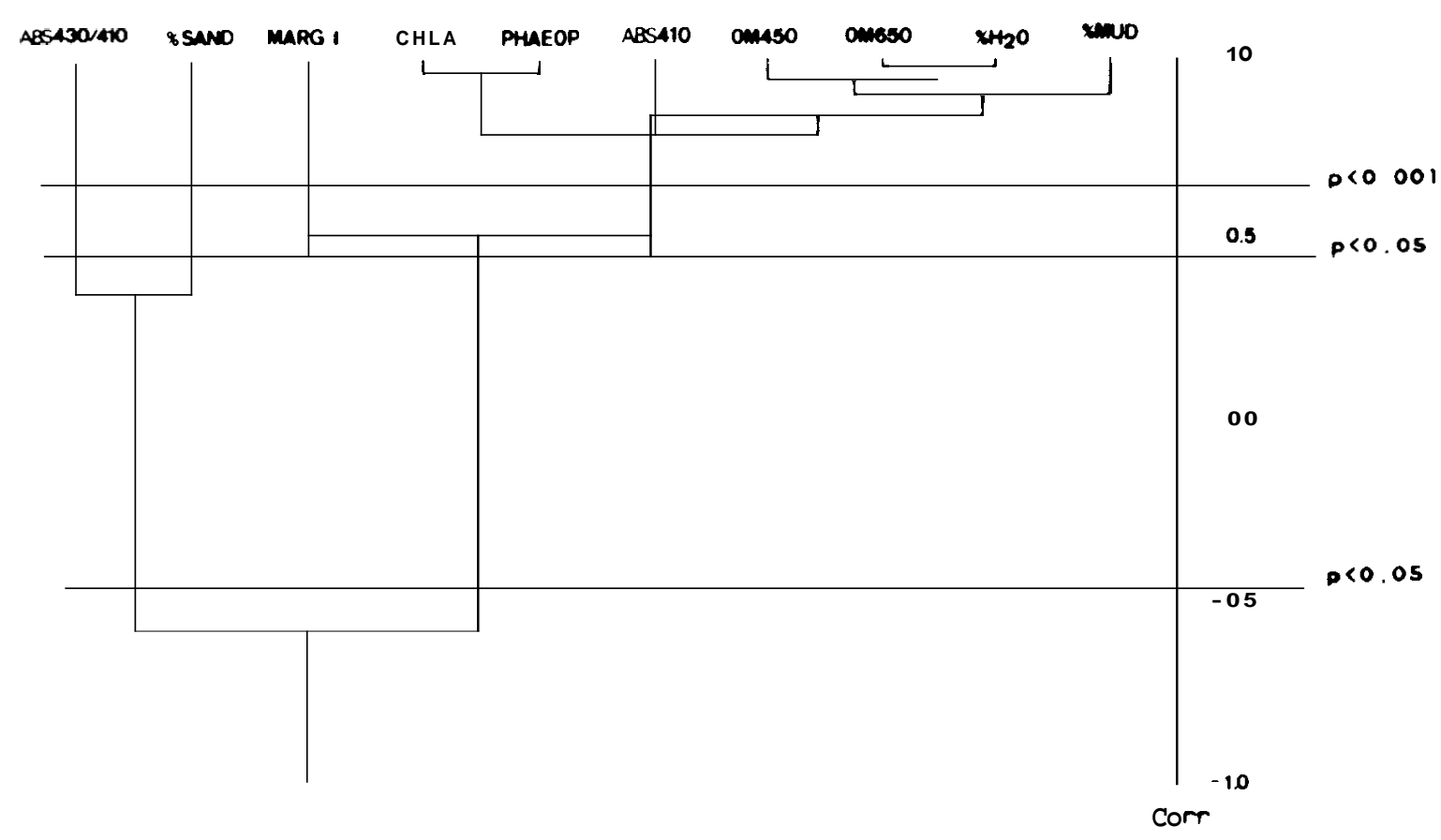

Figure 3.- Cluster analysis on sediment parameters (average values)

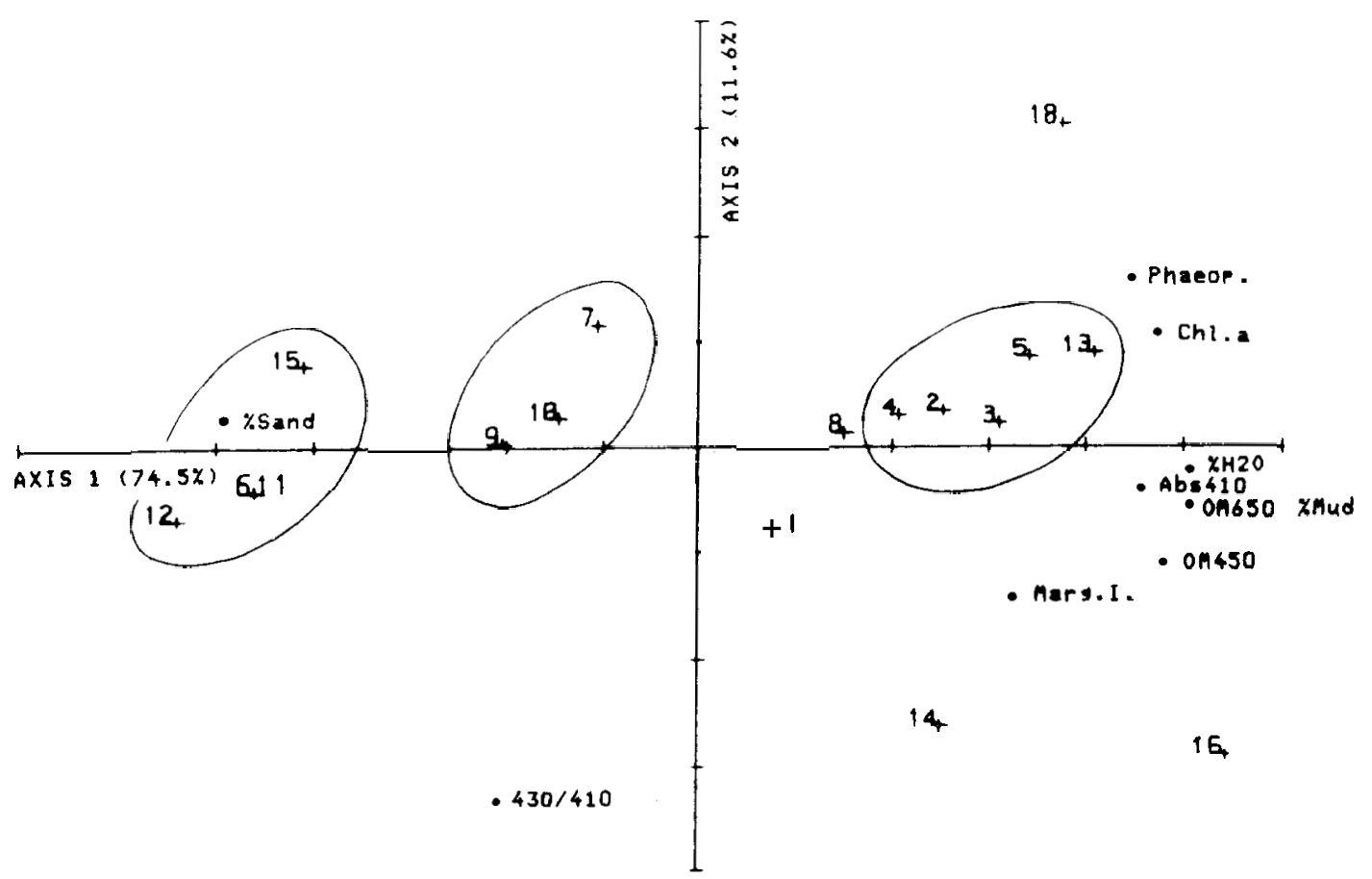

Figure4.- PrincipalComponents Analysis onsediment parameters (average values) 
OM 450 and Om 650 are strongly correlated $(p<0.001)$ suggesting a similar distribution of the factors responsible for differences at the two temperatures (e.g. carbonates). Organic matter is generally highespeciallyin rnud sediments. There is a strong correlation ( $p<0.001)$ between OM and rnud \%.

As with organic matter, sediment water content follows the grain-size variation, being positively correlated $(p<0.001)$ with rnud $\%$ and negatively ( $<<0.001$ ) with sand $\%$.

The regression line between sediment water content (13\%-83\%)and its dry specific weight (DSW) is expressed by:

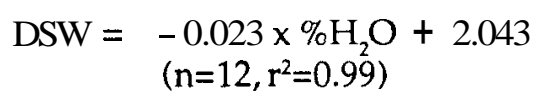

Phytopigments, both chlorophilla and phaeopigments, are present in larger concentration in muds than in sands. Average values for sands are $52.6 \mathrm{mg} / \mathrm{m}^{2} \mathrm{chl}$ a and $126.8 \mathrm{mg} / \mathrm{m}^{2}$ phaeop and for muds $256,6 \mathrm{mg} / \mathrm{m}^{2}$ and $775,8 \mathrm{mg} / \mathrm{m}^{2}$, respectively.

\section{DISCUSSION}

Sediment water content, because of its strong correlation $(p<0.001)$ with rnud $\%$ and with sand $\%$, undoubtly represents an effective physical index. Its value is necessary for phytopigrnents determination and was used to obtain phytopigment concentration per unit area from concentration per sediment weight. Providing an excellent correlation with DSW it makes the diagnosis of sediment granulometric type possible. Very easily and rapidly obtainable it is a practica 1 and useful instrument in sediment characterisation.

The position of 430/410 vector in PCA (Fig.4), separated frommud and related parameters, and the negative correlation between $430 / 410$ and rnud and itsgrouping withsands in clusteranalysis (Fig. 3), suggests the applicability of this ratio in the understanding of production-deposition processes, confirming Moss (1967). According to this author,430/410 may beconsidered a productivity indicator. In sand areas of St Andrélagoon the degradation index is lower than in muds and
$430 / 410$ values are close to 1 . For monthly results of $430 / 410>1,64 \%$ wererecordedinsands, $15 \%$ in sandy-muds and $21 \%$ in muds. These values confirm the fact that, when comparing productive processes with deposition ones, the former are relatively more important in sand than in rnud stations. The ecological meaning of 430/410 ratio is supposed to be rather similar to Degradation index or Margalef's index, with 430/410, Moss (1967)pretended to get a chlorophyll/phaeopig-

Table I.Comparison of chl a data in coastal sediments

\begin{tabular}{|c|c|c|}
\hline $\begin{array}{l}\text { Loch Ewe } \\
\text { - sand }\end{array}$ & $3-20 \mu g / g$ & Steele* Baird (1978)' \\
\hline $\begin{array}{l}\text { Ythan Estuary } \\
\text { - rnud intertidal }\end{array}$ & $25-34 \mu \mathrm{g} / \mathrm{g}$ & $\operatorname{Leach}(1970)^{*}$ \\
\hline \multicolumn{2}{|c|}{$\begin{array}{l}\text { South New England } 100 \mathrm{mg} / \mathrm{m}^{2} \\
\text { - mixed, intertidal }\end{array}$} & Marshalletal (1971)* \\
\hline $\begin{array}{l}\text { Mediterranean } \\
\text { - sand, }>12 \mathrm{~m}\end{array}$ & $24-64 \mathrm{mg} / \mathrm{m}^{2}$ & Colocoloff $(1972)^{*}$ \\
\hline $\begin{array}{l}\text { ChuchiSea } \\
\text { - mud and sand, }>5\end{array}$ & $\begin{array}{l}40-320 \mathrm{mg} / \mathrm{m}^{2} \\
5 \mathrm{~m}\end{array}$ & $\begin{array}{l}\text { Matheka \& Horner } \\
\text { (1974)' }\end{array}$ \\
\hline $\begin{array}{l}\text { Wadden Sea } \\
\text { - sandy-mud, interti }\end{array}$ & $\begin{array}{l}40-440 \mathrm{mg} / \mathrm{m}^{2} \\
\text { idal }\end{array}$ & $\begin{array}{l}\text { Cadée \& Hegeman } \\
\text { (1977)' }\end{array}$ \\
\hline $\begin{array}{l}\text { Lynher Estuary } \\
\text { - mud, intertidal }\end{array}$ & $30-80 \mu \mathrm{g} / \mathrm{g}$ & Joint(1978)' \\
\hline $\begin{array}{l}\text { Ems Dollard Estuary } \\
\text { - mud, intertidal }\end{array}$ & $\mathrm{y} 33-184 \mathrm{mg} / \mathrm{m}^{2}$ & $\begin{array}{l}\text { Colijn \& Yonge } \\
(1984)\end{array}$ \\
\hline $\begin{array}{l}\text { Laholm Bay } \\
\text { - sand \& silty sand, }\end{array}$ & $\begin{array}{l}5-75 \mathrm{mg} / \mathrm{m}^{2} \\
>20 \mathrm{~m}\end{array}$ & Sundback (1986) \\
\hline $\begin{array}{l}\text { Tejo Estuary } \\
\text { - mud, intertidal }\end{array}$ & $130-180 \mathrm{mg} / \mathrm{m}^{2}$ & $\begin{array}{l}\text { Brotas \& Catarino } \\
\text { (1984) }\end{array}$ \\
\hline $\begin{array}{l}\text { Bretagne } \\
\text { - mud, intertidal }\end{array}$ & $19.5 \mu \mathrm{g} / \mathrm{g}$ & Riaux (1982) \\
\hline $\begin{array}{l}\text { Ebrié Lagoon } \\
\text { - sand, }\end{array}$ & $\begin{array}{l}0.5 \mathrm{~m}: 178 \mathrm{mg} / \mathrm{m}^{2} \\
5 \mathrm{~m}: 6 \mathrm{mg} / \mathrm{m}^{2}\end{array}$ & Plante-Cuny(1975) \\
\hline $\begin{array}{l}\text { Nosy-Bé } \\
\text { - sand }(5 \mathrm{~m}) \\
\text { - muddy sand }(5 \mathrm{~m})\end{array}$ & $\begin{array}{r}11.95 \mu \mathrm{g} / \mathrm{g} \\
4.99 \mu \mathrm{g} / \mathrm{g}\end{array}$ & Plante-Cuny (1977b) \\
\hline $\begin{array}{l}\text { St André Lagoon } \\
\text { - sand } \\
\text { - mud }\end{array}$ & $\begin{array}{l}53.6 \mathrm{mg} / \mathrm{m}_{2}(2.18 \mu \\
256,6 \mathrm{mg} / \mathrm{m}_{2}(46.26\end{array}$ & $\begin{array}{l}\text { this study } \\
g / g) \quad \text { (average } \\
\mathrm{g} / \mathrm{g} / \mathrm{g}) \quad \text { values) }\end{array}$ \\
\hline
\end{tabular}

* In Colijn \& Yonge (1984) 
mentsratio. however, nopositivecorrelationwas observed between them (Fig. 3).

The division of sediments in rich organic and productive muds and clean, less productivesands seems to support a nutrient limitation hypothesis for thislastcase, as Sundback (1986)also suggest.

Average phytopigment concentration -182.9 $\mathrm{mg} / \mathrm{m}^{2}$ chl a, $535.3 \mathrm{mg} / \mathrm{m}^{2}$ phaeop is considerably larger than in the water column $-27.6 \mathrm{mg} /$ $\mathrm{m}^{2} \mathrm{chl} \mathrm{a}, 15.5 \mathrm{mg} / \mathrm{m}^{2}$ phaeop (unpublished data). In coastal lagoons, unlike lakes, processes at the sediment level are more important than those in the water column. Sediment is a nutrient deposit of upmost importance and much of the systems productivity relies on microphytobenthos based food-chains. The high sediment productivityin a shallow lagoon such as St André is an essential part of the production of the system as a whole.

Average phaeopigment concentration of the sediment is three times larger than chl a. Phaeopigment concentration depends on phytoplankton sinking, macrophyte decomposition, perphyton and microphytobenthos. An accumulation process is observed along the annual cycle (Cancela da Fonseca et al, in litt).
In Spring, superficial sediment is washed out, at first by the lagoon water dischargeand after by tides. Consequently there is a decrease in phytopigment concentrations. Once the lagoon seals off, pigrnent values are approximately half the previous ones (Cancela da Fonseca, et al, in litt.). The effect is particularly noticeable for sands as most of the sand area is located in the lagoon channel.

There is not much data on sediment phytopigments of coastal lagoons. Most of the literature concernsopen systems such as estuaries. Table 1 presents data on open and closed, marine or brackish, environrnents. Santo André chloropyll a has among the highest concentrations.

\section{ACKNOWLEDGEMENTS}

Financial support provided by Instituto Nacional de Investigação Científica, Project "Estrutura, Dinâmicae Produçãode Ecosistemas Estuarinos e Lagunares Costeiros".

The authors express their thanks to Paulo Fernandes for improving the English.

\section{RESUMEN}

\section{LAGUNA DE SANTO ANDRÉ (S.O. PORTUGAL): FITOPIGMENTOS DEL SEDIMENTO COMO MARCADORES}

Durante los últimos años, el estudio de la clorofila y sus derivados en el sedimento ha venidosiendocada vez más utilizado para entender la producción de los sedimentos. St. André es una laguna costera de agua salobre con gran cantidad de materia orgánica en el sedimento superficial. En este trabajo se analizan los datos de fitopigmentos, materia orgánica (determinada por combustión), contenido de agua y granulometría del sedimento. Dos zonas de distinta productividad han resultado muy relacionadas con los principales tipos de sedimentos: arenas y fangos.

Los feopigmentos resultaron muy correlacionados con la materia orgánica confirmando su origen vegetal. Los sedimentosfangosos presentan una concentración mayor de pigmentos, pero también en la zona arenosa predomina la producción sobre los procesos de sedimentación.

\section{REFERENCES}

ANDRADE, F. (1986):Oestuáriodo Rio Mira: Caracterizaçãogeral eanálise quantitativa da estrutura dos macropovoamentos bentónicos. Tese de Doutoramento, Fac. Cienc. Lisboa, 393 p.
Birch, P. B.; Barnes, R. S.; SpYridakis, D. E. (1980): Recent sedimentation and its relationship with primary productivity in four Western Washington lakes. Limnol. Oceanogr., $25(2): 240-247$. 
Brown, S. R.; Daley, R. J.; McNeely, R. N. (1977): Composition and stratifigraphy of the fossilphorbin derivatives of Little Round Lake, Ontario. Limnol. Oceanogr., 22 (2): 336-348.

Buller, A. T.; McManus, J. (1979):Sediment sampling and analysis. In: Estuarine hydrographyand sedimentation. A handbook (Dyer, K. R. ed.): 87-130. Cambridge Univ. Press, London. $230 \mathrm{p}$.

Brotas, V.; Catarino, F. (1984):Microfitobentos do estuário d o Tejo. Actas do $V^{9}$ Simpósio Ibéricode Estudos do Bentos Marinho, 3:119-129, Lisboa Maio-84.

Cancela da Fonseca, L.; Costa, A. M.; Bernardo, J. M., in litt. Breve caracterização ecológica da Lagoa de St Andrpe (1984-86). ( $2^{\circ}$ Congresso sobre o Alentejo. Maio 1985 - Vol II.

CARPENTER, R. S.; ElSER, M. M.; Elser, J. J. (1986): Chlorophyll production, degradationand sedimentation: Implications for paleolimnology. Limnol. Oceanogr., 31 (1):112-124.

Colijn, F.; DE Jonge, V. N. (1984):Primary production of microphytobenthos in the Ems-Dollard estuary. Mar. Ecol. Prog. Serv. 14: 185-196.

Daley, R. J.; Brown, S. R.; McNeely, R. N. (1977): Cromatographicand SCDP measurements of fossil phorbins and the postglacial history of Little Round Lake, Ontario. Limnol. Oceanogr., 22 (2):349-360.

DuXIN, H. (1984):Upwelling and sedimentation Dynamics - $\mathbf{I}$. The role of upwelling in sedimentation in the Huanghai sea and EastChina sea-a description of'general features. Chin. J. Oceanol. Limnol., 2 (1): 12-19.

FogG, G. E.; Belcher, J. H. (1961): Pigments from the bottom deposits of an english lake. New Phytologist, 60 (2):129-142.

FONSECA, R, M. (1985): Caracterização do ambiente sedimentar da Lagoa de St ${ }^{\circ}$ André. Estágiode Licenciatura de Geologia, F.C.L., policopiado, 108 p.

Fox, D. L.; Anderson, L. J. (1941): Pigments from marine muds. Proc. Nat. Acad. Sci., 27: 333-336.

Fox, D. L. (1944): Biochemical fossils.Science, 100 (2589): 111-113.

Graneli, W.; Sundback, K. (1986):Can microbenthic photosynthesis influence below-halocline oxygen conditions in the Kattegat? Ophelia, 26: 195-206.

Lubimenko, M. V. N.; Rauser-Cernooussova (1930): Paléobotanique. Sur les restes fossiles de la chlorophylledans les sédiments limoneux marins. C.R. Acad. Sci. Paris, 190: 813-815.

Moss, B. (1967): A spectrophotometric method for the estimation of percentage degradation of chlorophylls to pheo-pigments in extracts of algae. Limnol. Oceanogr., 12 (2):335-340.
Plante-CunY, M. R. (1974): Evaluation par spectrophotomètrie des teneurs en chorophyllea fonctionelleeten phéopigments dessubstrats meubles marins. Doc. Sci. Mission O.R.S.T.O.M.Nosy-Bé, 45: 1-76.

- (1975): Distribution selon la profondeur de la chorophyllea fonctionelle et des phéopigments sur les sédiments de la laguna Ebrié (Abidjan). C. R. Acad. Sc. París (série D), 281: 1325-1328.

Plante-CunY, M. R. (1977a): Pigments photosynthétiques et production primaire $\mathrm{du}$ microphytobenthos d'une lagune tropical, la Lagune Ébrié (Abidjan, Côted'Ivoire).Cah.O.R.S.T.O.M., sér. Oceanogr., XV (1):3-25.

- (1977b): Repartition à la surface et au sein du sédiment de la chlorophyll a et des phéopigments de quelques substrats meubles tropicauximmergés.J. Rech. Oceanogr. 2 (2):1-11.

- (1979):Lachlorophyll a fonctionnelledans les substrats meubles marins, indice de la biomase du microphytobenthos. Rapp. Comm. int. Mer Médit. 25/26, 4: 285-290.

ReYnolds, C.S.; Morison, H.R. AND ButTERwick, C. (1982): The sedimentary flux of phytoplankton in the South Basin of Windermere. Limnol. Oceanogr., 27 (6):1126-1175.

Riaux, C. (1982): La chlorophyll a dans un sédiment estuarien de Bretagne Nord. Ann. Inst. Oceanogr.58 (2):183-203.

SANCER, J.E.; GoRHAM, E. (1972):Stratigraphy of fossil pigments as a guide to the postglacial history of Kirchner Marsh, Minnesota. Limnol. Oceanogr., 17 (6):840-854.

SELLEY, R. S. (1976): An Introduction to Sedimentology. Academic Press, London, New York, San Francisco. 408 pp.

SuNDBACK, K. (1986): What are the benthic microalgas doing on the bottom of Laholm Bay?Ophelia,suppl. 4: 273-286.

SHuman, F.R.; LoRENZEN, C. J. (1975): Quantitative degradation of chlorophyll by a marine herbivore. Limnol.Oceanogr. 20(4).

VALLENTYNE, J. R. (1954): Biochemical Limmnology. Science, 119:605-606.

VALLENTYNE, J. R. (1955): Sedimentary chlorophyll determination as a paleobotanical method. Can. J. Botany, 33: 304-313.

VALlentMNE, J. R.; CRASTON, D. F. (1957): Cedimentary chlorophyll degradation products in surface muds from Connecticut Lakes. Can. J. Botany, 35: 35-42. 